\title{
The Revelation of Religion's Enlightenment to the Teaching of Political Theory Course in Military Academy
}

\author{
Bian Kaiyue \\ Department of Political Work, Army Engineering University, Nanjing 210007 \\ 248653308@qq.com
}

Keywords: religious communication methods; political theory teaching

Abstract: The number of faiths in religions has risen sharply in recent years, however, among which, the unique means of religious communication plays an extremely important role. Therefore, it is proposed that the teaching of political theory courses in military academies should be based on the life world to determine the content and form of political theory teaching, and actively cultivate "missionaries" scholars. Political theory teaching workers shall strive to achieve the organic combination of political theory teaching and Chinese traditional festivals.

\section{Introduction}

Since the 1970s, a wave of religious revival has quietly set off in the world. The rapid development of Chinese religion since the 1980s has also become part of the global religious renaissance. For more than 30 years, the number of religious believers has achieved "big expansion", and the religious structure has undergone tremendous changes: from the closure of religious sites to reforms. The restoration of the early days of openness and the spectacular and splendid nature of the temple's view of the temple today have led to a diversity of religious believers, diverse organizational systems, and religious life. The religious revival has political, economic, cultural and social changes and many other reasons. Among the many reasons, the unique religious belief education and its mode of transmission play an extremely important role in exploring its unique charm. The military school political theory teaching has significant implications.

\section{The Unique Mode of Transmission of Religion}

\subsection{The blending with the secular cultural life in China has allowed religion to survive}

The three major religions of Buddhism, Christianity and Islam successively settled in the land of the Chinese nation, and in their unique ways had a profound and far-reaching impact on the knowledge and behavior of the Chinese people. In the process of their introduction to China, each religion was restricted by the "gold laws" of the survival of the fittest. They all paid attention to the issue of doing as one would go along with the countryside, and made significant progress in nationalization and localization. 
At the end of the Western Han Dynasty, Buddhism was first introduced to China. At that time, people lacked understanding and understanding of Buddhism. At that time, people always used the ideas of Chinese deities to understand or explain foreign Buddhism. In addition, in the Han and Wei period, there was still the idea of Confucianism. Buddhism has gradually found the basis of spiritual immortality and karma in the classic Chinese Confucian classics, thus making Buddhism easy to spread on our country's land. When Buddhism began to flourish in the Wei and Jin Dynasties, the popularity of the Wei and Jin metaphysics provided important ideological conditions for the prosperity of Buddhism. In order to adapt to the current ideological trend of the time, Buddhists began to use the metaphors of the Wei and Jin Dynasties to understand and interpret the Buddhist Prajnakongka, forming the fusion and integration of the two thoughts of Buddha and Xuan. During the Southern and Northern Dynasties, Buddhism was widely spread. At this time, the spread of Buddhism abandoned the practice of interpreting and adhering to Buddhism thoughts with Chinese inherent thoughts, and it can correctly grasp the meaning of Buddhist classics. At this time, the integration of Buddhism and China's inherent culture has continued. In the early period of the Sui and Tang dynasties, there emerged a Buddhist sect where the Buddhism was no longer the period for the introduction and digestion of Indian Buddhism during the period of the South and the North. It was the period of Chinese Buddhism's innovation and the establishment of a Chinese Buddhism different from the Indian Traditional Buddhism. In the middle and late Tang Dynasty, the Zen Buddhism fused Zen Buddhism with the Chinese Confucian theory of human nature, Taoist intuitionism, and even embraced the spirit of traditional Chinese cultural traditions such as the traditional Chinese philosophy of simplicity. The fusion of Chinese and Indian cultures took shape. Become a Buddhist sect with Chinese characteristics - Zen. [1]

In addition to Buddhism adapting to China's inherent secular life and cultural characteristics that have spread in China, the spread of Christianity and Islam in China is also true. The Italian Jesuit Missionary Matteo Ricci, who was a missionary to China at the end of the Ming Dynasty, studied Chinese and four books and five classics. When the first church was created, it was dressed and claimed to be desecrating. Afterwards, Confucian scholars, officials, and royal family members of the Ming Dynasty were brought together. This course of "integrating Confucianism with Confucianism" has achieved great success. Ricci sowed the seeds of a Catholic civilization for thousands of years in the capital of the feudal dynasty led by Confucianism. [2] The spread of Islam is also true. Its teachings, ethical thoughts and moral cultivation are also faced with reality. This has enabled Islam to receive more than 10 ethnic minorities in China, forming their unique historical and cultural traditions, fine ethical and moral customs and rituals. The system was then merged into Chinese Islamic culture with Chinese characteristics.

\subsection{Religious people are the driving force behind religious communication}

Whether it is Buddhism, Christianity or Islam, the world's three major religions can be widely spread around the world, and it is inextricably linked with the efforts of numerous believers and innumerable religious figures. Throughout ancient and modern religious people, their noble personality charm has deeply infected their followers. Jian Zhen takes a sea-voyage eastward to Japan after 12 years. He hadn't succeeded in crossing the sea 5 times. Although he was blind afterwards, he nevertheless managed to reach Japan. Xuan Zang traveled westwards and learned the truth through numerous hardships. Matteo Ricci is brilliant, witty; Puncak is not afraid of violence and defends the truth. In China, whether it is Christianity, Buddhism or Islam, there is no exception to the cultivation of the noble personality of the believers. Take Buddhism as an example, the basic requirement for becoming a monk or bhikuni is to be noble. Such as: "Pure beliefs, diligent study of three studies, observance of teachings and canons, correct conduct," "reliable beliefs, abstaining 
from purity, deeper Buddhist attainments, moral conviction, and high prestige", etc. There is a higher demand for becoming a chair. We must set an example, lead people to repair, maintain permanent residence, take the public, be loyal to their duties and be honest and clean. [3]

In addition, many religious people have profound knowledge. Many of them have not only profound religious theory knowledge, but also have great achievements in philosophy, music, painting, astronomy, geography and other disciplines. The vast majority of Islam's teachings and teachings in the past ten years have received rigorous and systematic religious education and the teaching of their predecessors and their own efforts has led many of them to develop not only a noble moral sentiment but also a wealth of religion, knowledge of social sciences and natural sciences. In Germany, Christian priests are proficient in many disciplines and not limited to theology. Many of them are religious people and knowledgeable scholars. In short, the high moral charisma of religious people, profound knowledge, and belief in religious devotion deeply affect believers and make people feel convinced and eventually embark on the road to religious belief.

\subsection{Religious festivals carry the past, present and future of religion}

The continued development of religion in the world is due in large part to countless religious festivals. Whether it is to commemorate the Buddha's birthday when Buddha Sakyamuni was born, to commemorate Buddha's enlightenment during Sakyamuni's enlightenment, to celebrate the death of Shakyamuni's Nirvana, or to commemorate the birth of Jesus Christ and establish Christmas to commemorate the resurrection of Jesus. Easter, Thanksgiving thanks to the gift of God, or the sacred commemoration of Muhammad's birthday, and the Eid al-Adha, Eid al-Fitr, etc. Numerous religious festivals bring together systematic religious doctrines and normative ritual traditions. They are standardized through religious etiquette programs, so that religious doctrines are deeply rooted in the souls of believers and flow into the blood of their descendants. From the beginning to the end of its formation, religion, a cultural phenomenon peculiar to human beings, has gone through centuries of vicissitudes, but it is still alive and will continue to be inherited in the future.

\section{The Revelation of the Method of Religion Communication to the Teaching of Political Theory course in Military Academy}

\subsection{Determine the content and form of political theory teaching based on the life world}

Whether it is Buddhism, Christianity, or Islam, they were able to adapt to people's original beliefs, original thinking, and way of life in the process of their introduction to China, and they were gradually accepted by people. They were eventually believed by people. This has great implications for the teaching of political theory in military academies. For a long time, the teaching of political theory courses in military academies has obviously lacked pertinence and appeal in terms of content and form. It has separated the teaching of political theory from the world of life of educated people. Teachers often follow their own concerns or the books of dogmas. The basis of knowledge is to select mechanically inculcated moral provisions that have long been recognized in the society, so that educators feel that these contents are large and empty, far from their own lives, and unable to produce a mind with political theory teaching. As a result of collisions, the "invalid state" or "marginal situation" of the military school political theory teaching appears. It can be seen that "the generalization and absoluteness of indoctrination education is not only out of step with the times due to its over-emphasis on politics, but also because of the way that you hit me with the times. [4]

Dewey once proposed that "education is life" and "school is society". Tao Xingzhi has repeatedly emphasized "education for life" and "education based on life." To this end, the content 
and form of the teaching of political theory courses in military academies should be able to adapt to the students of different ages, adapt to the actual conditions of the students in different times, and live in reality; they can be closely combined with the students' interests and hobbies, and can adapt to the psychological orientation and knowledge of different students. There are specific issues such as how much, high intelligence, acceptance characteristics, comprehension, and focus. In short, the teaching of political theory in military academies should continue to improve and enrich their contents and forms based on students' world of life, and constantly shorten the distance between educators and political theory teaching, and then improve the effectiveness of political theory teaching.

\subsection{Training "missionary" teachers of political theory}

\subsubsection{The teachers of political theory should have noble personality charm}

The world's three major religions, without exception, pay attention to the cultivation of the noble personality of the believers. It is precisely because of the stringent requirements of its moral qualities and its own self-assured practice that the noble personal charm that religious people have has profoundly affected the people of the world, so that these people in the world are believed to be their believers and even believe in their religion. The teachers of political theory courses must assume the dual tasks of "qualified teacher" and "excellent teacher" and must make their education attractive. [5] The acquisition of this charisma depends not only on words, but also on physical education. Physical education emphasizes the potential influence of educators' personal cultivation and personality charm on educators. To be a model of virtue for others is a kind of personality charm. Comrade Jiang Zemin pointed out in his "Conversation on Education Issues": "As teachers of human souls, teachers must not only teach good books but also cultivate good people, the teaching methods of political theory instructors are not only textbooks in their hands, but more importantly they are based on their noble personality and character." The personality charm of political theory teachers is a tremendous spiritual force. The impact on students is subtle, profound, long-term, and lifelong benefits.

Jaspers emphasised that "education is generation", which is "the spirit that fits one another and the culture is transmitted." [6] To this end, we can think that there is a hidden communication environment between educators and educators in the teaching of political theory. This hidden communication environment may be mutual respect between the educator and the educational object, and the worship may also be considered as exclusion or contradiction. Undoubtedly, the educator's own good personal cultivation and noble personality charm can promote the healthy operation of the exchange environment between the educator and the educator, thus achieving this kind of interpersonal spiritual fit.

\subsubsection{Political theory teachers should have firm beliefs and strong professional identity}

Throughout ancient and modern times, it is not difficult to find that whether it is a famous religious person or a general communication person, one of their common characteristics is their complete acceptance and firm belief in their own religious teachings and beliefs. Based on this, they again show people the charm of religion. Those who have more influence join the ranks and regard teaching to people as a great cause as an important way to realize the value of life. It is because of this that we find that religious believers' missionary activities are all-pervasive, pervasive, and endless.

Political theory instructors are also ideals, communicators and defenders of beliefs. This means that teachers of political theory must first of all have firm beliefs, adhere to the world outlook of 
dialectical materialism and historical materialism, and have a strong sense of identity in the work they are engaged in, and realize the importance of their profession. And there is a desire to devote life to this profession. Only one's own beliefs can enable the educated to believe deeply that they can produce the appeal of education and improve the effectiveness of political theory teaching.

\subsubsection{The teacher of political theory should have profound Marxism and theoretical literacy of Marxism in China}

To become a qualified teacher of political theory, it is required that it should have profound Marxism and theoretical literacy of Marxism in China. Liu Yandong also mentioned in his speech "Strengthening and improving the ideological and political theory classes in universities and arming college students with the theoretical system of socialism with Chinese characteristics": "Building a high level of Marxist theoretical literacy, a solid knowledge of the humanities and social sciences, learning Chinese and Western culture and Deep-knit team." Only with a high level of Marxist theory and quality can we stand tall and look far, and we will have strong insights, analytical problems, and ability to solve problems. Only in this way can we have stronger predictability and understand and execute the supportive party. The basic line and basic program of the government can only adhere to the correct political direction.

\subsection{Advocate the organic combination of political theory teaching and Chinese traditional festivals}

The continued development of religion in the world is due in large part to countless religious festivals. Religious festivals unite religious doctrines and normative ceremonial traditions of the system and are deeply rooted in the souls of believers, and they flow in the blood of their descendants and are handed down from generation to generation, although religion has been a cultural phenomenon peculiar to humanity since its formation, it has survived centuries of vicissitudes, but it is still alive. Religious festivals of various forms resemble a huge stone that not only firmly attracts believers, they are willing to pay homage to that illusory, unreal existence, and it also applies its magic to the land of the souls of the non-teachers. At last, they gradually sprouted religious species.

The Chinese nation, which has a history of five thousand years of civilization, has many traditional festivals. These traditional festivals, as cultural symbols of the nation, imply the common values, moral standards, and behavioral norms of social groups. To this end, the political theory teaching in Chinese universities should be organically integrated with China's traditional festivals to strengthen the propaganda of traditional festival culture; continue to tap the core spirit of traditional festival culture, release the sense of belonging of national culture; increase the traditional festival experience, carry forward the national cultural tradition. Create a good external environment for the military theory teaching in military academies.

\section{Conclusion}

Military academies are the hope of the military's future motherland. They are both successors and defenders of the socialist cause in our country. Their moral qualities, beliefs, and values will, to a large extent, directly determine the forces and the cause of socialism with Chinese characteristics. With regard to the future and destiny, we should use the Marxist religious concept as a guide, actively explore and draw lessons from the positive elements of religious communication methods and apply them to the existing political theory teaching, we have given me little support for the teaching of political theory courses in our army. 


\section{References}

[1] Xu Kangsheng. The Sinification of Buddhism [M]. Religious Culture Press, 2008, 8.

[2] See: Li Suju, Youth Faith and Religion Culture [M]. Oriental Press, 2009.10.

[3] Chinese Buddhism Association. Method for the qualification of Buddhist teaching staff in the Han Dynasty [s], 2010, 1(10).

[4] Zha Xuezhen. Educational Research: The Return of Ideological and Political Education in Colleges and Universities to the Life World [J]. Journal of Tongling College (Humanities and Social Sciences)2009.

[5] Zhang Yaocan, Lu Aixin. On the Educational Charm of Political Theory Teachers [J]. School Party Building and Political Theory Teaching, 2005, (1).

[6] Nie Dujuan. Jaspers' Theory and Teaching of Political Theory in Military Academy, Heilongjiang Higher Education Research, 2009. 